\title{
Denetim Komitesi Özelliklerinin Firma İhtiyatlılık Düzeyine Etkisi: BIST'te Bir Uygulama
}

\author{
Gökhan Özer c, Abdullah Kürşat Merter b, d
}

\section{Özet}

$\mathrm{Bu}$ çalışmada, finansal raporlama kalitesinin göstergesi olarak belirlenen şirketlerin ihtiyatlılık düzeyleri ile 5 temel denetim komitesi özelliği (bağımsızlık, finansal uzmanlık, boyut, görev süresi, toplantı sayısı) arasındaki ilişki incelenmiştir. Bu kapsamda, 2012-2016 yılları arasında BİST'te işlem gören 263 şirketten elde edilmiş 1180 adet gözlem kullanılarak panel veri analizi yapılmış ve denetim komitesi özelliklerinin şirketlerin ihtiyatlılık düzeyleri ile ilişkisi test edilmiştir. Araştırma yöntemi olarak literatürde en çok tercih edilen yöntem olan "Kar/Hisse Senedi Getirisi" modeli olarak ifade edilen Basu modeli kullanılmıştır. Bulgular, ihtiyatlılığın denetim komitesi boyutu ile pozitif, toplantı sayısı ile negatif ilişkili olduğunu göstermektedir. Sonuçlar, denetim komitesi üye sayısının artması durumunda, komitelerin daha etkin hale geldiğini ve firma ihtiyatllık düzeyini arttırarak finansal raporlama kalitesinin yukarıya çektiğini göstermektedir. Buna karşın, denetim komitesinin dönem içinde daha sık toplantı gerçekleştirmesi durumunda firma ihtiyatlılık düzeyi düşmekte ve buna bağlı olarak finansal raporlama kalitesi azalmaktadır.
Anahtar Kelimeler

Denetim Komitesi İhtiyatlılık

Basu Modeli

Kurumsal Yönetim

Makale Hakkında

Geliş Tarihi: 29.11.2018

Kabul Tarihi: 20.11.2019

Doi: 10.18026/cbayarsos.485075

\section{The Effect of Audit Committee Characteristics on Firm Conservatism Level: An Application in BIST}

\begin{abstract}
In this study, the relationship between the conservatism levels of companies determined as an indicator of financial reporting quality and the 5 basic audit committee characteristics (independence, financial expertise, size, tenure, number of meetings) is examined. In this context, panel data analysis is applied using 1180 observations obtained from 263 publicly-traded company between 2012 and 2016, and the audit committee characteristics are tested in relation to the companies' conservatism levels. As the research method, Basu Model, the most preferred method in the literature, is used. Findings show that while the audit committee size is positively related to conservatism, the number of meetings is negatively related to conservatism. The results show that if the number of members of the audit committee increases, it becomes more effective and increases the level of conservatism, thus raising the quality of financial reporting. On the other hand, if the audit committee meets more frequently during the period, the level of conservatism decreases and the quality of financial reporting decreases accordingly.
\end{abstract}

Keywords

Audit Committee

Conservatism

Basu Model

Corporate Governance

About Article

Received: 29.11.2018

Accepted: 20.11.2019

Doi: 10.18026/cbayarsos.485075

c Prof. Dr., Gebze Teknik Üniversitesi, İşletme Fakültesi, ORCID: 0000-0002-3255-998X

b İletişim Yazarı: akmerter@gut.edu.tr

d Arş. Gör., Gebze Teknik Üniversitesi, İşletme Fakültesi, ORCID: 0000-0001-6874-1890 


\section{Giriş}

Denetim komiteleri, yaşanan muhasebe skandallarının (örneğin Enron, WorldCom, HIH) ve büyük ekonomik krizlerin (örneğin, Asya Finansal Krizi, Küresel Mali Kriz) ardından son yirmi yıldır kurumsal yönetim literatüründe oldukça ilgi gören yapı haline gelmiştir (Sultana, 2015). Yönetim kurulu, bir firmanın finansal raporlama sistemi için nihai sorumluluğa sahip bir yapı olarak görülse de günümüzde yaşanan muhasebe skandalları ve ekonomik krizlerin ardından bu sorumluluk yavaş yavaş denetim komitelerine devredilmektedir (Lara, Osma ve Penalva, 2009). Nitekim birçok ülke, sermaye piyasalarında işlem gören şirketlerin denetim komitesi kurmalarını zorunlu kılmış, daha şeffaf ve güvenilir finansal tablolar çıkarmaları için denetim komitesi üyelerinin bağımsız ve finansal uzmanlığa sahip olmaları gerektiğini belirtmiştir. Yapılan araştırma sonuçları incelendiğinde de denetim komitesi üyelerinin bağımsız olması ve finansal uzmanlığa sahip olmasının finansal raporlama kalitesini arttırdığı görülmektedir (DeFond ve Francis, 2005; Dhaliwal, Naiker ve Navissi, 2010; Krishnan ve Visvanathan, 2009; Joseph vd., 2006). Ayrıca bu çalışmalarda, denetim komitesi özelliklerinin finansal tablolarda raporlanan karın kalitesini yükselttiği ve yöneticilerin, şirket karlarını olduğundan daha fazla göstermelerine olanak sağlayan kar yönetimi uygulamalarını kısıtladığı gösterilmektedir.

Muhasebenin temel ilkelerinden biri olan ihtiyatlılık, yöneticilerin fırsatçı davranışlarını kısıtlayan ve muhasebe kayıtlarında yapılan ihlalleri hizla önleyerek finansal raporlama kalitesini arttıran önemli bir ilkedir (Zhong, 2016). 2010 yılında Uluslararası Muhasebe Standartları Kurulu (IASB) ve Finansal Muhasebe Standartları Kurulu (FASB) tarafından önerilen ortak kavramsal çerçeveden çıkarılmasına rağmen, günümüzde hala birçok şirketin benimsediği önemli bir ilkedir. Nitekim yapılan birçok ampirik çalışmalarda (Pae, Thornton ve Welker, 2004; Sultana, 2015; Kao ve Chu 2016; Lim 2011; LaFond ve Watts 2008) şirketlerin ihtiyatlı muhasebe politikaları izlediği görülmektedir. Ayrıca bu çalışmalarda ihtiyatlılığın, kar yönetimi, bilgi asimetrisi, vekalet maliyetleri gibi sorunları azalttığını ve şirketlerde kurumsal yönetim anlayışını geliştirdiği gözlemlenmiştir. Bu yazarlar, ihtiyatlılığa özellikle finansal raporlama aşamasında ihtiyaç duyulduğunu ve ihtiyatlılığın yöneticilerin fırsatçı davranışlarını engellediği için finansal raporlardaki bilgilerin güvenilirliğinin ve doğruluğunun arttığını savunmaktadırlar.

Denetim komiteleri 1970'li yıllardan itibaren Amerika'da ve İngiltere'de ilgi gören bir yapı olmasına rağmen, ülkemizde ancak 2011 yılında Sermaye Piyasası Kurulu tarafından yapılan düzenleme ile ön plana çıkmıştır (Tuan, 2015, 116). Özellikle 2002 yılında patlak veren Enron skandalı sonrası Amerika'da Sarbanes Oxley yasasının çıkartılması ve İngiltere'de Smith Komitesi (2003) kararların alınması, şirketlerin yönetim yapısında, denetim işleyişinde ve finansal raporlarında önemli değişikliklerin meydana gelmesine neden olmuştur (Hellman, 2008). Amerika ve İngiltere' deki düzenlemeler ile birlikte, denetim komitesi üyelerinin tamamının bağımsız olması, komitede en az bir üyenin finansal uzmanlığa sahip olması ve yılın belli aralıklarına toplanması zorunlu hale gelmiştir. Ülkemizde ise SPK düzenlemesi (2011) ile birlikte borsada işlem gören şirketlerin denetim komiteleri kurmaları, komitelerde en az 2 üyenin bulunması, komite üyelerinin bağımsız olması ve komitenin yılda en az 4 kere toplanması zorunlu kılınmıştır.

Denetim komitesi ile ilgili ampirik araştırmaların odak noktası, denetim komitelerinin firma performansı (Aldamen vd. 2012), kar kalitesi (Johnson, Daily ve Ellstrand, 1996; Chancharat, Krishnamurti ve Tian, 2012; Bedard, Chtourou ve Courteau, 2004; Klein, 2002a; 2002b) ve 
özellikle de kar yönetimi (Fengyi 2014; Abbott, Parker ve Peters, 2004; Bédard vd., 2004; Zalata, Tauringana ve Tingbani, 2018) üzerindeki etkisine yönelik olmuştur. Öte yandan, literatürde denetim komitesi özellikleri ile ihtiyatlılık arasındaki ilişkiyi kapsamlı bir şekilde araştıran çalışmalar oldukça kısıtlıdır. (DeFond ve Francis 2005; Ahmed ve Henry 2012; García vd., 2009; Ahmed ve Duellman, 2007, Ahmed ve Duellman, 2012; Klein 2002a; Lim 2011) gibi yazarlar, yönetim kurulu özelliklerinin ihtiyatlıkla ilişkisi üzerine durmuşken; (Sultana, 2015; Krishnan and Visvanathan, 2008; Kao ve Chu, 2016) gibi yazarlar, denetim komitesi özellikleri ile ihtiyatlılık arasındaki ilişkiye yönelik kapsamlı çalışmalar yapmıştır.

Ülkemizde ise denetim komitesi ile ilgili çalışmaların odak noktası kar yönetimi, iç denetim etkinliği ve finansal raporlama zamanlılı̆̆ olmuştur. Yavuzaslan ve Kalmış (2016) çalışmasında, en önemli kurumsal yönetim mekanizmalarından olan yönetim kurulu ve denetim komitesinin bağımsızlı̆̆ının kar yönetimi uygulamalarını kısıtladığını ortaya koymuştur. Ağca ve Önder (2016), denetim komitesi ve yönetim kurulu üye sayısının kar yönetimi uygulamalarını arttırdığını ancak yönetim kurulu ve denetim komitesi bağımsızlığının kar yönetimi uygulamalarını azalttığını göstermiştir. Temiz, Dalkılıç ve Hachasanoğlu (2017), yönetim kurulu üye sayısın ve cinsiyet çeşitliliğinin kar yönetimi uygulamalarını azalttığını ve denetim komitesi üye sayısının kar yönetimi uygulamaları ile ilişkili olmadığını ortaya koymuştur. Sevim ve Eliuz (2007), denetim komitesi varlığı ile iç denetim etkinliği arasındaki ilişkiyi araştırmış ve denetim komitesi kuran şirketlerde iç denetim etkinliğinin kısmi bir şekilde arttığını ortaya koymuştur. Cengiz (2017), denetim komitesi özellikleri ile denetim raporlarının yayınlanma süresi arasındaki ilişkiyi araştırmıştır. Araştırmanın sonuçları, denetim komitesi üye sayısının raporlama süresini kısalttığını, toplantı sayısının ise raporlama süresini arttırdığını ortaya koymuştur. Tuan (2016), 2012-2013 yıllarında Borsa İstanbul'da işlem gören 434 halka açık şirketten elde ettiği verilerden hareketle denetim komitesi özellikleri ile piyasa değeri defter değeri oranını kullanarak tahmin etmeye çalıştığı ihtiyatlılık arasındaki ilişkiyi incelemiştir. Araştırma sonuçları, denetim komitesi üyelerinin meşguliyeti ile ihtiyatlılık arasında pozitif ilişki olduğunu göstermektedir.

Şirketlerin muhasebe ve raporlama sürecinin gözetiminde önemli bir rol üstlenen denetim komiteleri, finansal tabloların oluşturulmasında ve kamuoyuna finansal bilgilerin sunulmasında ihtiyatlı muhasebe politikaları izlemesi gerekmektedir. Muhasebenin temel ilkelerinden birisi olan ihtiyatlılık kavramı gereği, şirketler gerçekleşmesi olası olan kötü durumları finansal tablolara daha hızlı aktarırken, gerçekleşmesi olası iyi durumları birçok doğrulama kademesinden geçirdikten sonra finansal tablolara aktarmaktadır (Watts, 2003). Bunun sonucunda daha şeffaf, daha güvenilir ve daha kaliteli finansal raporlar ortaya çıkmaktadır. Denetim komitesi ve ihtiyatlık arasındaki ilişkiye yönelik yapılan çalışmalar incelendiğinde (Sultana, 2015; Krishnan and Visvanathan, 2008; Kao ve Chu, 2016) denetim komitesi özellikleri ile ihtiyatlılık arasında güçlü bir ilişkinin olması beklenmektedir. Bu çerçevede çalışmanın temel amacı, BİST'te işlem gören şirketlerin denetim komitesi özellikleri ile ihtiyatlılık seviyeleri arasında ilişki olup olmadığını araştırmaktır. 2012-2016 yılları arasında BİST'te işlem gören şirketlerden elde edilen 1180 firma/yılı gözlem sayısı kullanılarak denetim komitesi özellikleri ile ihtiyatlılık arasındaki ilişki panel veri analizi yöntemi ile araştırılmıştır. Bulgular, bazı denetim komitesi özellikleri ile ihtiyatlılık arasında anlamlı bir ilişki olduğunu göstermektedir. 


\section{Literatür Taraması ve Hipotez Geliştirme}

Geleneksel olarak ihtiyatlılık, "kârları dikkate alma fakat bütün zararları dikkate al" ifadesiyle açıklanabilir (Acar ve Aktürk, 2009). İhtiyatlılık, özellikle son 30 yıllık dönemde muhasebe literatüründe oldukça tartışılan ve muhasebe politikalarına en fazla etki eden kavramlardan birisi olmuştur. Özellikle büyük muhasebe skandallarından sonra kurumsal yönetim anlayışının gelişmesi ve Uluslararası Muhasebe Standartlarının tüm dünyada kabul görmesi, bu kavramın daha çok tartışılmasına neden olmuştur (DeFond ve Francis, 2005). İhtiyatlılık kavramına yönelik literatürde yapılan ilk tanım, "kâr amacı gütmeden tüm zararları öngörmek" şeklindedir (Bliss, 1924). Bu tanım yapıcı olabilir ancak oldukça basittir. FASB (1975) ihtiyatlılığı, “Gelecekte alınması ya da ödenmesi gereken iki tutar tahminlerinin eşit olması muhtemelse, ihtiyatlılık daha az iyimser olanın kullanılması gerektiğini" şeklinde ifade etmektedir.

1990'lı yıllarda şirketlerin ihtiyatlılık seviyesinin istatiksel olarak ölçülmesi için ilk çalışmaları yapan ve bir model geliştiren Basu (1997), ihtiyatlılık için yeni bir tanım önermiştir. Basu (1997)'nun geliştirdiği tanım ve model literatürde oldukça yaygın bir şekilde kullanılmaktadır. Basu (1997), ihtiyatlılığ "finansal tablolardaki iyi haberleri kötü haberlerden daha yüksek bir dereceye kadar doğrulama eğilimi" olarak tanımlamaktadır. İhtiyatlılık ilkesine göre şirketler, kötü haberleri (muhtemel gider ve zararlar) iyi haberlere (muhtemel gelir ve karlar) göre finansal tablolara daha hızlı yansıtmaktadır. İyi haberler, zaman içinde kademeli olarak finansal tablolara yansıtılırken, kötü haberler fazla doğrulama yapılmadan finansal tablolara yansıtılmaktadır. Başka bir ifadeyle, iyi haberler ile kötü haberler arasında bir zamanlılık asimetrisi söz konusudur. İhtiyatlılık sayesinde şirketler, kötü haberleri derhal muhasebeleştirmekte ve bu kötü haberlerin temel nedenlerini belirleyerek daha hizlı bir şekilde harekete geçebilmektedir (Yunos, Ahmad ve Sulaiman, 2014).

Watts (2003), ihtiyatlılığın yöneticilerin fırsatçı davranışlarını sınırlayabileceğini, firmaların değerini artırabileceğini ve böylece azınlık hissedarlarının çıkarlarını koruyabileceğini ifade etmektedir. LaFond ve Watts (2008), ihtiyatlılığın, yöneticilerin olumsuz bilgiyi saklamalarını engellediğini, başka bir ifadeyle, bilgi asimetrisini azalttığını savunmaktadır. Lara vd., (2009)'un İngiltere' de iflas eden şirketlere yönelik yaptığ 1 çalışmada, şirketlerin iflas etmeden önce daha az ihtiyatlı muhasebe politikaları izlediklerini ortaya koymuştur. Ahmed ve Duellman (2007), ihtiyatlılığın, yöneticiler ile pay sahipleri arasındaki çıkar çatışmalarını engellediğini ve vekalet maliyetlerini düşürdüğünü ileri sürmektedir. Ahmed ve Duellman (2011), daha ihtiyatlı muhasebe politikaları izleyen şirketlerin brüt kar marjları ve nakit akışlarının diğer şirketlere göre daha yüksek olduğuna dair bulgular elde etmiştir.

Yapılan birçok ampirik çalışmada, ihtiyatlılığın, kar yönetimi, bilgi asimetrisi, vekalet maliyeti gibi sorunları engellediği ve şirketlerde kurumsal yönetim anlayışının geliştirilmesinde önemli bir etken olduğu ortaya koyulmuştur. Ancak (García vd., 2012; Fengyi 2014) gibi yazarlar, ihtiyatlılık ile kar yönetimi arasında pozitif bir ilişki olduğunu ve ihtiyatlılığın kar manipülasyonuna neden olduğunu savunmaktadır. FASB (2010) ihtiyatlılığın, yanlı bilgilerin muhasebeleştirilmesine neden olduğunu ve muhasebenin temel ilkelerinden olan tarafsızlık ilkesini zedeleyen sonuçlar doğurduğunu ileri sürmektedir. Ayrıca, Pae (2007) ihtiyatlılık uygulamaları sonucunda işletme varlıklarının bilançoya olduğundan daha düşük değerle yansıtıldığı ve bunun sonucunda da finansal tablolarda yanlış bilgilerin yer aldığını iddia etmektedir. Son olarak, günümüzde gerçeğe uygun değer yönteminin piyasaya, yatırımcılara ve diğer paydaşlara şirket hakkında daha gerçekçi bilgiler sunması ve ihtiyatlılığın bu bilgilere 
ulaşımı sınırlandırdığı ve hatta engellediği düşüncesi ihtiyatlılığa olan bakış açısını değiştirmiştir. Tüm bunların sonucunda, 2010 yılında Uluslararası Muhasebe Standartları Kurulu tarafından kavramsal çerçeveden çıkartılmıştır.

Denetim komitelerinin görevlerini ve sorumluluklarını en etkin bir şekilde yerine getirebilmeleri için belirli özelliklere ve bu özelliklerin doğru bir kombinasyonuna sahip olması gerekmektedir (Sultana, 2015). Denetim komitesi ve ihtiyatlılık arasındaki ilişkiye yönelik yapılan çalışmalara bakıldığında (Sultana, 2015; Krishnan and Visvanathan, 2008; Kao ve Chu, 2016) denetim komitesinin beş temel özelliğine (Bağımsızlık, finansal uzmanlık, boyut, toplantı sıklığı, görev süresi) odaklanıldığı görülmektedir. Bu nedenle çalışmada denetim komitesinin ihtiyatlılık üzerine etkisini ölçmek için bu beş temel denetim komitesi özelliklerine odaklanılmıştır. Ayrıca çalışmamızda, denetim komitesi özellikleri ile arasında tamamlayıcılık ilişkisi bulunan yönetim kurulu özellikleri (Yönetim kurulu boyutu, bağımsızlığı ve CEO-Yönetim kurulu başkanı ayrımı) ve firmaya özgü özellikler (firma büyüklüğü, piyasa değeri / defter değeri ve kaldıraç oranı) kontrol değişkeni olarak kullanılmıştır.

Çalışmada kullanılan denetim komitesinin beş temel özelliğinin şirketlerin ihtiyatlılık seviyelerine etkisini ölçmek için hipotezler geliştirilmiştir.

\section{Finansal Uzmanlik}

SEC tarafından 2002 yılında yapılan düzenleme ile Amerikan şirketlerinin, denetim komitelerinde en az bir finansal uzman çalıştırması zorunlu hale gelmiştir. Ayrıca bu finansal uzmanın sadece muhasebe konusunda uzmanlaşmış olması gerektiğini vurgulamıştır (SEC 2002). Ancak birçok firmanın, özelliklede küçük ölçekli olanların, muhasebe alanında uzmanlaşmış denetim komitesi finansal uzmanlarını cezbetmekte zorlandığını, denetim komitesi finansal uzmanının, denetim fonksiyonunu yerine getirmek için güçlü bir muhasebe geçmişine ihtiyacının olmaması ve finansal tabloların kamuoyuna duyurulmasının denetim komitesi finansal uzmanına ek sorumluluk yüklemesi bu dar tanımın genişletilmesi ihtiyacını doğurmuştur (SEC 2003). SEC, denetim komitesi finansal uzmanının tanımını, muhasebe dışı finansal uzmanlarını da (finans ve denetimde uzmanlaşmış) kapsayacak şekilde genişleterek bu tür sorunların giderilmesini amaçlamıştır (Joseph vd., 2006). Ülkemizde ise denetim komitesinde en az bir finansal uzmanın görevlendirilmesi ile ilgili olarak herhangi bir yasal zorunluluk bulunmamaktadır. Bu tür görevlendirmeler, şirketlerin inisiyatifine bırakılmıştır.

Literatürde denetim komitesinin finansal uzmanlığı konusunda birçok çalışma mevcuttur. Bedard vd., (2004) ve Krishnan (2005)'nın yaptıkları çalışmalarda, finansal uzmanlığın daha az kar yönetimi ve daha iyi iç kontrol ile ilişkili olduğunu göstermişlerdir. DeFond ve Francis (2005), finansal uzmanlığının kurumsal yönetim uygulamalarında tamamlayıcı rol üstlendiğini savunmaktadır. Abbott vd., (2004) ve Agrawal ve Chadha (2005), denetim komitesinde finansal uzmana sahip olan firmaların finansal raporlarında düzeltme yapma ihtimalinin daha düşük olduğunu iddia etmektedirler. Krishnan ve Lee (2009)'in yaptığ çalışmada, yüksek finansal dava açılma riskine sahip olan firmaların denetim komitelerinde finansal uzmanlığa sahip üyelere daha fazla yer verdikleri sonucuna ulaşılmıştır. Buna göre, finansal uzmanlığa sahip kişiler, denetim raporlarında ve mali tablolarda gerçekleşebilecek olası hataları en aza indirdikleri için bu firmaların sahip olduğu yüksek dava riski en aza inmektedir. Aldamen vd., (2012) denetim komitesinde finansal uzmanın bulundurulmasının 
firma performansı arttırdığını gösteren bulgular elde etmiştir. Sultana (2015) gerçekleştirdiği çalışmada, ihtiyatlılık ile denetim komitesinde finansal uzmanlığa sahip yöneticilerin varlığ arasında pozitif ilişki bulmuştur. Krishnan ve Visvanathan, (2008) finansal uzmanlığa sahip denetim komitesi olan firmaların daha ihtiyatlı muhasebe politikaları uyguladığını ileri sürmektedir.

Yukarıdaki argümanlar dikkate alındığında aşağıdaki hipotez oluşturulmuştur:

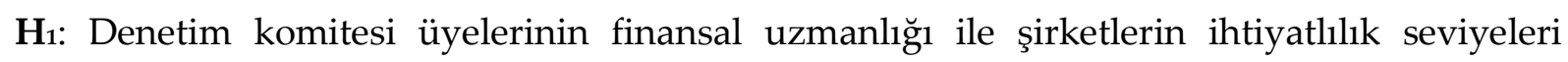
arasında pozitif bir ilişki vardır.

\section{Bă̆ımsızlık}

Denetim komitesinin finansal uzmanlığının yanı sıra bağımsızlığı da denetim kurulunun en önemli özelliklerinden birisidir. Denetim komitesinin bağımsızlı̆̆ının önemi, denetim komitesinin bağımsız yöneticilerden oluşmasını gerektiren düzenleyici kurallara dayanmaktadır (Fakhari ve Pitenoei, 2017). Bu sebeple Amerika'da, İngiltere'de, Türkiye'de ve diğer birçok ülkede denetim komitelerinin tamamen bağımsız üyelerden oluşması zorunlu hale getirilmiştir.

Johnson vd., (1996); Chancharat vd., (2012); Bedard vd., (2004); Klein, (2002b) denetim komitesinde bağımsız yöneticilerin bulunmaması durumunda, finansal raporlama sürecindeki kusurların artacağını ve CEO'ların agresif kar yönetimine başvurabileceğini belirtmişlerdir. Buna ek olarak, bağımsız yöneticilerin varlığının finansal raporlama yanı sıra iç ve bağımsız denetimin kalitesini arttırdığını ve vekalet maliyetlerini düşürdüğünü savunmuşlardır. Appiah ve Amon (2015), bağımsız denetim komitelerinin kurumsal iflas olasılığını azalttığı savını ileri sürmektedirler. Hassan, Hijazi ve Naser (2016), etkili bir denetim komitesinin şirketlerin yönetim kurulu özelliklerine ve mülkiyet yapılarına ikame veya tamamlayıcı bir mekanizma olarak etki edip etmeyeceğini araştırmış ve denetim komitesinin etkinliğinin, yönetim kurulu ile birleştirildiğinde "karşılıklı güçlendirme" yoluyla daha etkin hale geldiğini ortaya koymuştur. Fakhari ve Pitenoei (2017), denetim komitesi bağımsızlığının ve finansal uzmanlığının bilgi asimetrisini azalttığını ve firmanın bilgi çevresine olumlu katkılar sağladığını göstermiştir. Joseph ve Terry (2003), çalışmalarında denetim komitesinde bağımsız olmayan üyelerin oranı ile firmaların finansal sıkıntı içine girme olasılığı arasında güçlü bir ilişki bulmuştur. Klein (2002b), denetim komitesinin bağımsızlığının yönetim kurulu büyüklüğü ve bağımsızlığı ile pozitif ilişkili, hızlı büyüme ve firma zararları ile negatif ilişkili olduğuna dair bulgular elde etmiştir.

Yukarıdaki argümanlar dikkate alındığında şu hipotez oluşturulmuştur:

$\mathbf{H}_{2}$ : Denetim komitesindeki üyelerin bağımsızlığı ile şirketlerin ihtiyatlılık seviyeleri arasında pozitif bir ilişki vardır.

\section{Boyut}

Denetim komitesi boyutunun, denetim komitesi faaliyetlerini büyük ölçüde etkilemesi ve finansal raporlama üzerinde daha etkin bir kontrol gücüne sahip olmasını sağlaması beklenmektedir. Öte yandan denetim komitelerinde üye sayısının fazlalığı, karar alma 
kalitesini de düşürebilmektedir. Literatürde denetim komitesinin boyutu ile ilgili iki zıt görüş mevcuttur.

Abbott vd. (2004) ve Bedard vd. (2004), yaptıkları çalışmalarda denetim komitesinde 3'ten fazla üye bulunması durumunda, firmaların daha az finansal hata yaptıklarını göstermişlerdir. Ayrıca denetim komitelerinde 3 veya daha fazla üyenin bulunmasının, yöneticilerin agresif kar yöntemlerine başvurmalarına kısıtlayıcı etkide bulunduğunu ve komitenin potansiyel finansal raporlama süreci ile ilgili sorunları hızlı bir şekilde çözebildiğini ortaya koymuşlardır.

Karşıt görüş olarak ise Bushman, Piotroski ve Smith, (2004) ve Piot (2004) gibi araştırmacılar; büyük kurulların iletişim koordinasyonu konusunda sorun yaşadıklarını, küçük kurulların karar alma sürecinde daha hızlı olacaklarını, bunun sonucunda da kaliteli denetim faaliyetlerinin ortaya çıkacağını belirtmektedirler. Aldamen vd. (2012) 2008 krizinde, firma performansı ile denetim komitesi üye sayısı arasında negatif bir ilişkinin olduğunu göstermiştir.

Yukarıdaki argümanlar dikkate alındığında aşağıdaki hipotez oluşturulmuştur:

$\mathbf{H}_{3}$ : Denetim komitesi üye sayısı ile şirketlerin ihtiyatlılık seviyeleri arasında pozitif bir ilişki vardir.

\section{Görev Süresi}

Denetim komitesindeki üyelerin uzun süre görev yapmaları, bilgi, uzmanlık ve kalite açısından önemli bir unsur olarak görülmektedir (Sultana, 2015). Başka bir ifade ile, komite üyesinin görev süresi ne kadar uzun olursa, finansal uzmanlığı o kadar yüksek olması beklenmektedir. Bu durumda komite üyelerinin görev süresinin, finansal raporlama ve denetim kalitesine olumlu bir katkı sunması beklenir. Öte yandan bağımsız yöneticilerin bir komitede uzun süre görev alması, yönetim kurulu ile olan uzun süreli ilişkiden dolayı bağımsızlığın ortadan kalkmasına neden olabilmektedir (Sharma ve Iselin, 2012). Bu durum, finansal raporlama ve denetim kalitesine olumsuz anlamda bir etki etmesi kaçınılmazdır. Literatürde denetim komitesi üyelerinin görev süresi ile ilgili iki zıt görüş mevcuttur.

Bedard vd. (2004), denetim kurulu üyelerinin ortalama görev süresinin kar yönetimi ile ilişkili olup olmadığını incelemiştir. Denetim kurulu üyelerinin daha uzun görev süresine sahip olduklarında kar yönetiminin kısıtlanacağına ilişkin önemli bulgular elde etmiştir. Vafeas, (2003)'a göre uzun süreli çalışan yöneticiler, zamanla yüksek itibara sahip olabilmektedirler. Zayıf performans itibarı zedeleyeceği için, bu yöneticilerin iş performanslarına daha fazla dikkat edeceklerini düşünmektedir. Liu ve Sun (2010) çalışmalarında, denetim komitesindeki bağımsız üyelerin görev süresinin, komitenin finansal raporlamanın gözetimindeki etkinliğini etkileyip etkilemediğini incelemiştir. Denetim komitesinde bağımsız olarak uzun süre görev yapan yönetici oranının kar yönetimi ile olumsuz ilişkili olduğuna dair güçlü bulgular elde etmiştir. Aldamen vd. (2011) 2008 krizinde, firma performansının, denetim komitesi tecrübeli üye sayısı ile olumlu ilişkili olduğu sonucuna ulaşmıştır.

Öte Yandan Canavan, Jones ve Potter, (2004)'e göre uzun süreli görev yapan yöneticiler daha az çalışmakta ve daha az istihdam edilmektedir. Şirketin sorunlarıyla ilgili yeni anlayış ve çözümlerden yoksundurlar. Ticari faaliyetler daha karmaşıklaştıkça ve daha hızlı bir şekilde değiştikçe, uzun süreli yöneticiler için teknoloji, finansal işlemler ve iş stratejileri ile ilgili 
değişiklikleri takip etmek gittikçe zorlaşmaktadır. Yeni yöneticiler, yeni fikirleri ve eleştirel düşünceyi yönetim kuruluna veya komiteye getirebilmektedir. Bununla birlikte, uzun süreli görev yapan yöneticiler yeni konularla uğraşmak için yetenekten yoksun olabilmektedirler. Uzun süreli görev yapan yöneticilerin, zamanla gelişen yönetimle dostça bir ilişki kurma olasılı̆̆ı daha yüksek olacaktır. Vafeas (2003) ve Bebchuk, Fried ve Walker (2002) tarafından yapılan araştırmalar, yönetimin yetkilerini yönetim kurullarının aday gösterme sürecini etkilemek için kullanabileceğini öne sürmektedir. Yönetimle güçlü kişisel bağları bulunan bağımsız yöneticilerin yeniden atanmaları ve uzun vadede pozisyonlarını korumaları daha olasıdır. Böylelikle, yönetim kurulundaki bağımsız yöneticilerin bağımsızlığı azalabilmektedir. Sharma ve Iselin (2012) çalışmalarında denetim komitesindeki bağımsız üyelerin görev süresinin finansal raporlamanın kalitesini düşürdüğünü ve bağımsız üyelerin bağımlı hale geldiğini savunmaktadır.

Yukarıdaki argümanlar dikkate alındığında aşağıdaki hipotez oluşturulmuştur:

$\mathbf{H}_{4}$ : Denetim komitesi üyelerinin görev süresi ile şirketlerin ihtiyatlılık seviyeleri arasında pozitif bir ilişki vardır.

\section{Toplantı Sıklı̆̆ı}

Birçok ülkede denetim komitesi üyelerinin bağımsız olması ve finansal uzmanlığa sahip olması zorunlu kılınmıştır. Aynı zamanda bu iki önemli özelliğe ek olarak, denetim komitesi üyelerinin belirli aralıklarda toplanması da bir gereklilik olarak görülmüştür. Nitekim ülkemizde SPK (2011) düzenlemesine göre, denetim komitelerinin yılda en az 4 defa toplanması zorunlu kılınmıştır. Denetim komitesi toplantı sıklığının artması, finansal raporlarda gözden kaçan hataları minimize etmek ve denetim faaliyetlerini sıkılaştırmak açısından faydalı olabilmektedir. Öte yandan toplantı maliyetleri, beklenen faydadan fazla olabilmekte ve firmalara ek bir maliyet yükü getirebilmektedir. Literatürde denetim komitesi toplantı sıklığı ile ilgili iki zıt görüş mevcuttur.

Sharma, Naiker ve Lee (2009), denetim komitesi toplantı sıklığının kurumsallık seviyesi ve kurumsal sahiplik ile olumlu bir ilişki olduğunu ortaya koymuştur. Ayrıca hızlı büyüyen firmalarda denetim komitesi toplantı sıklığının az olduğu sonucuna ulaşmıştır. Sultana (2015) ihtiyatlılık ile denetim komitesi toplantılarının sıklığı arasında olumlu bir ilişki olduğunu belirtmektedir.

Ghafran ve O'Sullivan (2017), denetim komitesi toplantı sıklığı ile denetim ücreti arasında olumlu bir ilişki olduğunu ortaya koymuştur. Başka bir ifade ile, denetim komitesi toplantı sıklığı arttıkça denetim çalışanlarına ödenen ücretler artmaktadır. Appiah ve Amon (2015) çalışmasında, denetim komitesi toplantı sıklığı ile kurumsal iflas arasında olumlu bir ilişki olduğunu ve denetim komitelerinin toplantı sıklığı arttıkça maliyetlerde de (örneğin, yöneticilerin toplantı ücretleri, yönetim zamanı) artış meydana geldiğini ve buna bağlı olarak hissedar değerinin düştüğü ve firmaların iflas etme olasılığının arttığını ileri sürmüştür.

Yukarıdaki argümanlar dikkate alındığında aşağıdaki hipotez oluşturulmuştur:

H5: Denetim komitesi toplantı sıklığı ile şirketlerin ihtiyatlılık seviyeleri arasında negatif bir ilişki vardır. 


\section{Araştırma Yöntemi}

\section{İhtiyatlılı̆̆ın Ölçülmesi}

Fama (1970) menkul kıymetlerin yeni bilgiye anında, tam ve doğru olarak tepki verdiği, menkul kıymet fiyatlarının rastlantısal olarak değiştiği, profesyonel yatırımcıların bağımsız olarak veya gruplar halinde normalin üstünde bir kazanç elde etmesinin mümkün olmadığ piyasaları etkin piyasalar olarak adlandırmıştır. Başka bir ifade ile piyasaların güçlü bir etkinlik düzeyine sahip olmaları durumunda, hisse senedi fiyatları elde edilebilir olan tüm bilgileri yansıtması ve finansal bilgilerin, hisse senedi fiyatların hızlı bir şekilde etkilemesi gerekmektedir. Ülkemizde yapılan çalışmalar, Türkiye hisse senedi piyasasının zayıf formda etkin olduğunu ortaya koymuştur (Zeren, Kara ve Ar1 2013; Eken ve Adalı 2008; Yücel 2016). Bu durum, menkul kıymet piyasalarındaki tüm bilgilerin fiyatlara yansıdığı ve geçmiş fiyat hareketlerine dayalı olarak fiyat tahminin yapılamayacağını göstermektedir. Etkin piyasa hipotezi gereği hisse senedi getirileri, zaman içindeki farklı türdeki bilgileri ve haberleri tam olarak yansıtması gerekmektedir (Zhong, 2016). Ancak Basu (1997), ihtiyatlılık kavramı gereği, etkin piyasalarda haberlerin farklı zamanlarda hisse senedi getirilerine yansıdı ğını ileri sürmüştür. Başka bir ifade ile kötü haberlerin iyi haberlere göre daha hızlı kara yansıdığını ve asimetrik zamanlılı̆̆ın ortaya çıktığını belirtmiştir. Basu (1997)'nin geliştirdiği ve firma hakkında her türlü haberi hızlı bir şekilde yansıtabilen bir araç olan hisse senetlerinin üzerinden ihtiyatlılığın ölçülmesini sağlayan Kar/Hisse Senedi Getirisi modeli çalışmamızın araştırma yöntemi olarak tercih edilmiştir.

Kar/Hisse Senedi Getirisi modeli, şirketlerin kamuya açıklanan haberlerinin fiyata olan etkisini temel alan ve haberlerin işletmenin fiyatına tam olarak etki ettiği varsayımı altında çalışan bir modeldir. Basu (1997), etkin piyasalarda hisse senedi getirileri kamuya açık bütün haberleri simetrik olarak ve hızlı bir şekilde yansıttığından "haberleri" ölçmek için hisse senedi getirisi değişkenini kullanmıştır. Hisse senedi fiyatları çeşitli kaynaklardan piyasaya gelen tüm bilgileri içermektedir. Dolayısıyla hisse senedi fiyat değişiklikleri dönemdeki haber gelişiminin bir ölçüsüdür (Ruch ve Taylor, 2015, 23). Basu (1997), kötü haberlerin iyi haberlere göre daha zamanında kara yansıdığı için, kardaki pozitif getirilerden daha çok negatif getiri ilişkisi bulmayı beklemektedir.

Basu modeli olarak da bilinen aşağıdaki panel veri regresyon formülü, ihtiyatlılık derecesini diğer bir deyişle asimetrik zamanlılığı ölçmek için kullanılır:

$X_{\text {it }} / P_{\text {it }}=\beta_{0}+\beta_{1} D R_{\text {it }}+\beta_{2} R_{\text {it }}+\beta_{3} R_{\text {it }} D R_{\text {it }}+\varepsilon_{\text {it }}$

$X_{i t}=t$ yılı firması için hisse başına kar

$P_{i t}=t$ yılı i firması için hisse senedi açılış fiyatı

$R_{i t}=t$ yılı i firmast için hisse senedi getirisi

$D R_{i t}=R$ negatifse $D R=1, R$ pozitifse $D R=0$

Özünde, Basu (1997) hisse senedi getirileri (R) üzerinde muhasebe karlarını (X / P) "iyi haberler" ve "kötü haberler" olarak firma yılları açısından ayrı ayrı göstermek istemektedir. Bir firma yılında, hisse senedi getirisi pozitif veya sıfırsa, yani $R_{i t}>0$ ise, iyi haberler olan bir firma yılı olarak kabul edilir. Bir firma yılında, hisse senedi getirisi negatif, yani $R_{i t}<0$ ise kötü haberler firma yılı olarak kabul edilir. Tahmin edilen eğim katsayısı ( $\beta_{2}$ ve $\left.\beta_{3}\right)$, haberlerin 
doğasına (yani işaretine) bağlı olarak, hisse senedi getirisinde somutlaşan haberlerin kara yansıma zamanlılı̆̆ını ölçer.

Şirketlerin ihtiyatlı olmaları durumunda, kar ve hisse senedi getirisi arasındaki ilişki Şekil 1'deki gibi olmaktadır. $X_{i t, ~}$ yılı i firması için hisse başına karı, $R_{i t,} t$ yılı i firması için hisse senedi getirisini göstermektedir. Şekil 1'de Çeyrek I, pozitif getiri ve pozitif karın olduğu gözlemleri, Çeyrek II, negatif getiri ve pozitif karın olduğu gözlemleri, Çeyrek III, negatif getiri ve negatif karın olduğu gözlemleri ve son olarak Çeyrek IV ise pozitif getiri ve negatif karın olduğu gözlemleri içermektedir. Bir şirket için kötü haberlerin olduğu dönemlerde, piyasa bu olumsuz durumu şirketin hisse senetlerine hizlıca yansitacak ve bunun sonucunda negatif hisse senedi getirisi söz konusu olacaktır. İhtiyatlılık gereği şirketler bu kötü haberleri karlarına hızlıca yansıtacakları için hisse başına kar ile hisse senedi getirisi arasında ciddi bir bağlantı olacaktır. Çeyrek II ve III dönemlerinde hisse başına kar ve hisse senedi getirisi arasındaki ilişkinin Çeyrek I dönemine göre daha yüksek olması beklenmektedir. Buna bağlı olarak Çeyrek II ve III dönemlerindeki eğim katsayısı $\left(\beta_{2}+\beta_{3}\right)$ Çeyrek I'e göre yüksek olacaktır.

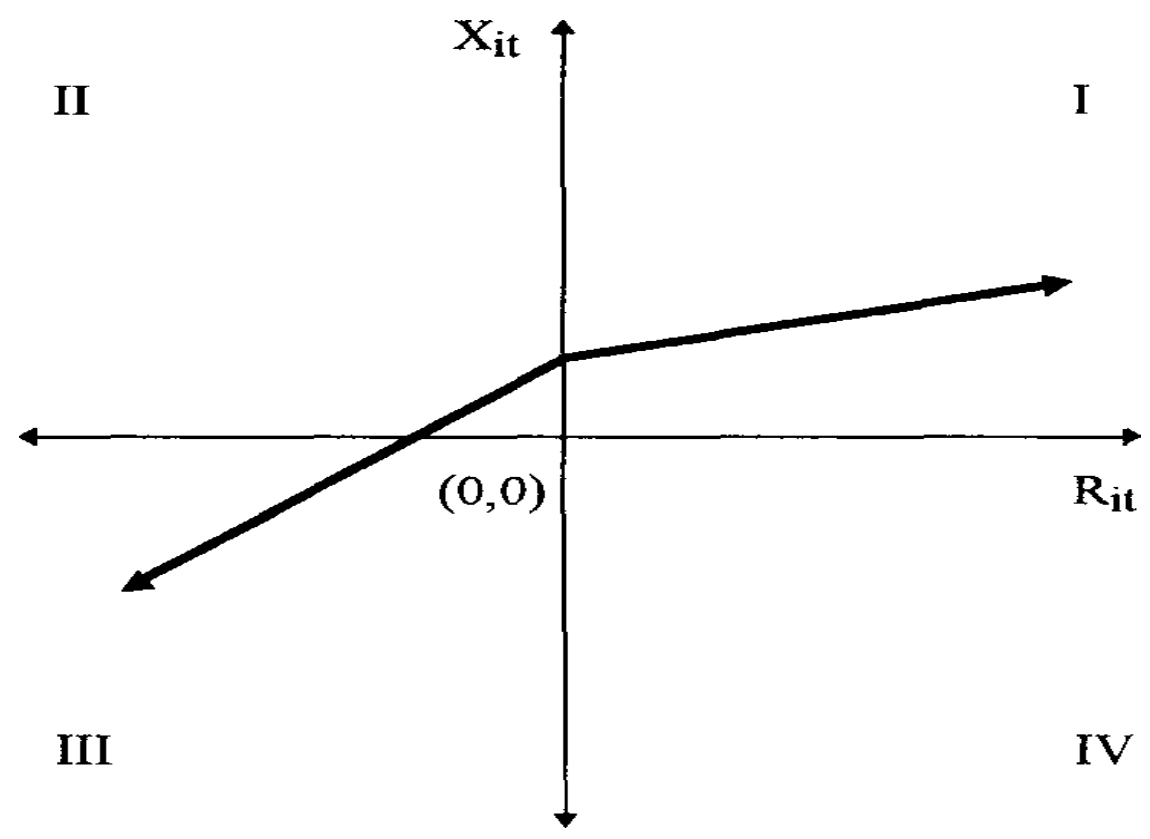

Şekil 1. Hisse Başına Kar ve Hisse Senedi Getirisi İlişkisi

Basu regresyon modeli, iyi haberler ile kötü haberler arasında ayrım yapmak için kukla değişken (DR) kullanmaktadır ve kukla değişken sayesinde eğim katsayılarının (ve kesişmelerinin) bu iki grup arasında farklı olmasına neden olmaktadır. İyi haberde $\left(R_{i t}>0\right)$, DR $=0$ 'dir ve iyi haber zamanlılık katsayısı $\beta_{2}$ 'dir. Kötü haberlerde $($ Rit $<0), \mathrm{DR}=1$ 'dir ve kötü haber zamanlılık katsayısı $\left(\beta_{2}+\beta_{3}\right)$ 'dir. $\beta_{3}$ asimetrik zamanlılık katsayısıdır ve ihtiyatlılığın Basu modelindeki başlıca göstergesidir. $\beta_{3}, 0^{\prime}$ dan ne kadar büyük olursa, ihtiyatlılık derecesi o kadar yüksek olacaktır (Zhe Wang, 2008).

\section{Denetim Komitesi Özelliklerinin Ölçülmesi}

Sultana, (2015); Krishnan and Visvanathan, (2008); Kao ve Chu, (2016) gibi yazarlar denetim komitesi ve ihtiyatlılık arasındaki ilişkiyi incelemek için denetim komitesinin beş temel 
özelliği üzerine odaklanmışlardır (Bağımsızlık, finansal uzmanlık, boyut, görev süresi, toplantı sıklığı). Literatürdeki çalışmalar incelendiğinde denetim komitesinin daha verimli çalışması ve kendisine verilen görevleri ve sorumlulukları yerine getirebilmesi için komite üyelerinin tamamının bağımsız olması, finans ve/veya muhasebe alanında uzman olması, belirli bir tecrübeye sahip olması, komitenin en az iki üyeden oluşması ve her yıl belirli aralıklarda toplanması gerektiği görülmektedir. Finansal tablolarda sunulan kara doğrudan etki eden ihtiyatlılık uygulamaları ile finansal tablolardaki bilgilerin doğruluğunu sağlamada en etkin bir şekilde çalışan denetim komitesi arasında bir ilişkinin olmaması mümkün görünmemektedir. Sonuç olarak, her bir denetim komitesi özelliği ile şirketlerin ihtiyatlılık seviyesi arasında istatiksel olarak anlamlı bir ilişkinin olması beklenmektedir.

Denetim komitesi bağımsızlı̆̆ı (DKBO olarak verilmiştir) denetim komitesindeki bağımsız yöneticilerin oranı ile ölçülmektedir. Denetim komitesi finansal uzmanlığı (DKFU); denetim komitesinde en az bir üye muhasebe, denetim ve finans konusunda uzmanlığa sahipse 1, değil ise 0 verilerek ölçülmektedir. Denetim komitesi boyutu (DKBT), denetim komitesi üye sayısı ile ölçülmektedir. Denetim komitesi görev süresi (DKGS), denetim komitesi yöneticilerinin komitedeki ortalama görev süreleri ile ölçülmektedir. Denetim komitesi toplantı sıklı̆̆ (DKTS) ise, denetim komitesinin bir yılda gerçekleştirdiği toplantı sayısı ile ölçülmektedir.

\section{Kontrol Değişkenlerinin Ölçülmesi}

Çalışmada, ihtiyatlılık ile ilişkili olduğu tespit edilen bazı yönetim bazlı ve firma bazlı özellikler kontrol altına alınmıştır (Sultana, 2015; Ahmed ve Duellman, 2007; Khan and Watts 2009).

Beekes vd., (2004), yönetim kurulu bağımsızlı̆ııın finansal raporlarda sunulan karın kalitesini arttırdığı savunmaktadır. Birçok çalışmada, çok sayıda bağımsız yönetim kurulu üyesine sahip olan firmaların finansal tabloların sunumunda sahtecilik yapma (Beasley ve Salterio, 2000) ve kar yönetimi faaliyetlerinde bulunma (Klein, 2002a; Lara vd., 2005) ihtimallerinin düşük olduğunu ortaya koymaktadır. Yönetim kurulu büyüklüğü konusunda ampirik sonuçlar karışıktır. Abbott vd. (2004) ve Bedard vd. (2004), küçük yönetim kurulların koordine edilmesinin daha kolay olduğunu ve bu kurullardaki yöneticiler daha az işten kaytarma problemine sahip olduğunu savunmaktadır. Bununla birlikte, Ahmed ve Duellman, (2007), daha büyük yönetim kurullarının daha deneyimli yöneticilere sahip olduğunu ve aynı zamanda bu kurullardaki yöneticilerin görevlerine daha fazla odaklandığını savunmaktadır. Bazı çalışmalar (Klein, 2002a; Vafeas, 2005), daha küçük kurulların, finansal hata ve agresif kar yönetimi gibi önemli finansal konuları ele almada daha etkili olduğunu ortaya koymuştur. Bununla birlikte, diğer araştırmalar, daha büyük kurulların firmaların finansal raporlamalarının kalitesini arttırdığını öne sürerek, karşıt bulgular elde etmişlerdir (Xie vd., 2003). Ahmed ve Duellman (2007), yüksek düzeyde bir yönetim kurulu bağımsızlığına sahip olan ve CEO-yönetim kurulu başkanı ayrımına giden şirketlerin denetim komitesi faaliyetlerinin daha etkin olduğunu savunmaktadır. Ampirik sonuçlar, CEO-yönetim kurulu başkanı ayrımının yapılmadığı durumlarda denetim faaliyetlerinin etkisiz olduğunu (Yunos, Ahmad ve Sulaiman, 2014; Klein, 2002) ve ayrımın yapıldı ğ şirketlerde denetim faaliyetlerinin oldukça güçlü bir mekanizma haline geldiğini ortaya koyulmuştur (Krishnan ve Visvanathan, 2008). Önceki literatürle tutarlı olarak yönetim kurulu bağımsızlığı (YKBO) yönetim kurulundaki bağımsız yöneticilerin oranı ile, yönetim kurulu boyutu (YKBT) yönetim 
kurulunda bulunun yönetici sayısı ile son olarak yönetim kurulu başkanı ve CEO ayrımı (YKB-CEO) yönetim kurulu başkanı ve CEO farklı kişiler ise 1; aynı kişiler ise 0 verilerek ölçülmüştür.

Lafond ve Watts (2008), büyük firmaların küçük firmalara göre daha az bilgi asimetrisine sahip olduklarını ve böylece büyük firmaların ihtiyatlılığa olan talebi azalttığını ileri sürmektedir. Lafond ve Watts (2008) ve Ahmed ve Duellman (2007), piyasa değeri / defter değeri yüksek olan firmaların mevcut varlıklarını büyütme açısından daha istekli olacakları için agresif muhasebe politikaları uygulama olasılıklarının yüksek olduğunu savunmaktadırlar. Ahmed vd. (2002) ve Lafond ve Watts (2008), daha yüksek kaldıraç oranına sahip firmaların, daha hızlı bir şekilde finansal sıkıntı içine girdikleri ve dava açılma risklerinin diğer firmalara göre daha yüksek olduğunu, bu nedenle, bu firmaların ihtiyatlı muhasebe uygulamalarına daha çok talep göstereceklerini savunmaktadırlar. Önceki literatürle tutarlı olarak firma büyüklüğü (FBÜ) piyasa değerinin doğal logaritması alınarak, Piyasa değeri / Defter değeri oranı (PD/DD) piyasa değeri ile defter değerinin birbirine oranlanmasıyla ve son olarak finansal kaldıraç (KAO) toplam borçların toplam varlıklara oranlanmasıyla ölçülmüştür.

\section{Örneklem ve Araştırma Bulguları}

\section{Örneklem Seçimi}

Örneklem, 2012-2016 yılları arasında BİST’te işlem gören 262 firmadan oluşmaktadır. Finansal tablolardaki farklılıklardan dolayı finansal şirketler ve gerekli verilerine ulaşılamayan şirketler analiz dışında bırakılması sonucu 1180 gözlemlik dengesiz panel veri setine ulaşılmıştır. Araştırma kapsamındaki şirketlere ait veriler, Finnet, BİST web sitesi, Kamuyu Aydınlatma Platformu web sitesi ve şirketlerin kendi web sitelerindeki yatırımcı ilişkileri sayfalarından elde edilmiştir.

\section{Tanımlayıcı Ístatistikler ve Korelasyon Matrisi}

Tablo I, analizde kullanılan değişkenlerin 2012-2016 yılları arasındaki tanımlayıcı istatistiklerini göstermektedir. Tablo incelendiğinde şirketlerin \%91,6'sının denetim komitelerini kurdukları görülmektedir. SPK (2011) düzenlemesine göre borsada işlem gören tüm şirketlerin denetim komitesi oluşturması zorunlu hâle getirilmiştir. Ancak payları yakın pazarda işlem gören şirketlerin denetim komitesi kurmaları zorunlu değildir. Ayrıca aynı düzenlemede denetim komitesi üyelerin bağımsız olması ve komitelerin yılda en az 4 defa toplanması zorunlu hale getirilmiştir. Borsada işlem gören şirketlerinde bu düzenlemede belirtilen unsurlara genel itibarıyla uyduğu görülmektedir. Sonuçlar, denetim komitelerinin 1,85 ortalama üye sayısına sahip olduğunu, bu üyelerin \%89,9‘nun bağımsız olduğunu ve komitelerin yılda ortalama 4 kere toplandığını göstermektedir. Ayrıca, SPK denetim komitesindeki üyelerin finansal uzmanlığı konusunda açık bir düzenleme getirmese de denetim komitesi üyelerinin \%53,3'ünün muhasebe/finans konusunda uzman olduğu görülmektedir. Son olarak, daha yeni sayılabilecek olan denetim komitelerinde, üyelerin görev sürelerinin ortalaması 2,27 yıl olarak gerçekleşmiştir. Bu sonuç, denetim komitesindeki üye 
sirkülasyonun az olduğunu ve buna bağlı olarak şirketlerin denetim komitesi üyelerinin tecrübeli olmasına önem verdiğini göstermektedir.

Tablo 1. Tanımlayıcı İstatistikler

\begin{tabular}{lcccc}
\hline Değişken adı & Ortalama & Standart sapma & Minimum değer & Maksimum değer \\
\hline X/P & 0,066 & 1,034 & $-3,147$ & 21,910 \\
\hline R & 14,615 & 55,282 & -99.087 & 518,625 \\
\hline DKVA & 0,916 & 0,277 & 0 & 1 \\
\hline DKBÜ & 1,859 & 0,585 & 1 & 3 \\
\hline DKBO & 0,899 & 0,296 & 0 & 1 \\
\hline DKTS & 4.027 & 1,503 & 2 & 1 \\
\hline DKFU & 0,533 & 0,499 & 0 & 15 \\
\hline DKGS & 2,278 & 1,357 & 1 & 0,615 \\
\hline YKBÜ & 7,05 & 2,131 & 3 & 1 \\
\hline YKBO & 0,296 & 0,104 & 0 & 34.723 \\
\hline YKB-CEO & 0,734 & 0,441 & 0 & 23,955 \\
\hline PD/DD & 1.747 & 2.634 & -20.385 & 8,674 \\
\hline ŞBÜ & 18,876 & 1,880 & 0,006 & 10 \\
\hline KAO & 0.519 & 0,411 & & 13 \\
\hline & & & 0 & 10 \\
\hline
\end{tabular}

Tablo II, tüm örneklem için pearson korelasyon matrisi sonuçlarını göstermektedir. Sonuçlar, beş temel denetim komitesi değişkenleri (Bağımsızlık, finansal uzmanlık, boyut, görev süresi ve toplantı sayısı) ile bağımlı değişken (Hisse başına kar / hisse fiyatı) arasında istatiksel olarak anlamlı ve pozitif ilişki olduğunu göstermektedir. Denetim komitesi boyutu ve bağımsızlığ arasındaki ilişki $(0,856)$ hariç hiçbir değişken arasında yüksek korelasyon bulunmamaktadır. Boyut ve bağımsızlık arasında çıkan yüksek korelasyon, denetim komitelerinin büyük çoğunluğunun 2 üyeden oluşması ve bu üyelerin bağımsız olmasından kaynaklanmaktadır. Tablo III'te değişkenler VIF değerleri verilmektedir. Hiçbir değişkenin VIF değeri 5 'ten yüksek olmadığı için boyut ve bağımsızlık değişkenlerinin analizden çıkarılmasına gerek görülmemiştir (Uygulama için bkz., Kao, ve Chu, 2016; Lim, 2011).

Son olarak, denetim komitesi değişkenleri arasındaki pearson korelasyon katsayılarının istatiksel olarak anlamlı ve pozitif olduğu görülmektedir. Diğer bir deyişle, denetim komitesi özellikleri birbirlerini tamamlamaktadır. 


\section{Özer \& Merter}

Tablo 2. Değişkenler Korelasyon Matrisi

\begin{tabular}{|c|c|c|c|c|c|c|c|c|c|c|c|c|c|}
\hline Değişkenler & $\mathrm{X} / \mathrm{P}$ & $\mathrm{R}$ & DKBÜ & $\mathrm{DKBO}$ & DKTS & DKFU & DKGS & YKBÜ & YKBO & $\begin{array}{l}\text { YKB- } \\
\text { CEO }\end{array}$ & PD/DD & ŞBÜ & $\mathrm{KA}$ \\
\hline $\mathrm{X} / \mathrm{P}$ & 1.000 & & & & & & & & & & & & \\
\hline $\mathrm{R}$ & $0.209^{*}$ & 1.000 & & & & & & & & & & & \\
\hline DKBÜ & $0.100^{*}$ & $0,061^{* *}$ & 1,000 & & & & & & & & & & \\
\hline DKBO & $0.087^{*}$ & $0,049^{* * *}$ & $0,856^{*}$ & 1,000 & & & & & & & & & \\
\hline DKTS & $0.049^{* * *}$ & 0,023 & $0,251^{*}$ & $0,248^{*}$ & 1,000 & & & & & & & & \\
\hline DKFU & $0.065^{* *}$ & 0,014 & $0.330^{*}$ & $0,330^{*}$ & $0,236^{*}$ & 1,000 & & & & & & & \\
\hline DKGS & $0.045^{* * *}$ & 0,031 & $0,452^{*}$ & $0,443^{*}$ & $0,484^{*}$ & $0,142^{*}$ & 1,000 & & & & & & \\
\hline YKBÜ & $0.103^{*}$ & $0,049^{* * *}$ & $0,198^{*}$ & $0,215^{*}$ & $0,237^{*}$ & $0,107^{*}$ & $0,133^{*}$ & 1,000 & & & & & \\
\hline YKBO & 0.026 & $-0,000$ & $0,521^{*}$ & $0,595^{*}$ & $0,412^{*}$ & $0,222^{*}$ & $0,218^{*}$ & $-0,212^{*}$ & 1,000 & & & & \\
\hline YKB-CEO & $0.157^{*}$ & $0,093^{*}$ & $0,177^{*}$ & $0,232^{*}$ & $0,204^{*}$ & $0,085^{*}$ & $0,073^{* *}$ & $0,278^{*}$ & 0,007 & 1,000 & & & \\
\hline PD/DD & $-0.060^{* *}$ & $0.109^{*}$ & $-0.105^{*}$ & $-0,067^{* *}$ & $-0,029$ & 0,003 & $-0,059^{* * *}$ & $-0,010$ & 0,027 & $-0,020$ & 1,000 & & \\
\hline ŞBÜ & $-0.175^{*}$ & $0,197^{*}$ & $0,186^{*}$ & $0,201^{*}$ & $0,233^{*}$ & $0,134^{*}$ & $0,152^{*}$ & $0,491^{*}$ & 0,020 & $0,290^{*}$ & 0,228 & 1,000 & \\
\hline $\mathrm{KAO}$ & $-0.152^{*}$ & $-0,042$ & $0,054^{* * *}$ & 0,035 & $0,065^{* *}$ & 0,021 & $0,049^{* * *}$ & $-0,051^{* * *}$ & $0,077^{*}$ & $-0,106^{*}$ & $-0,010$ & $-0,057^{* * *}$ & 1,000 \\
\hline
\end{tabular}

Not: I. *, ${ }^{* *},{ }^{* * *}$ simgeleri sırayla değişkenlerin \%1, \%5 ve \%10 seviyelerinde anlamlı olduğunu göstermektedir. II. Değişkenlerin açıklamaları Ek-1'de gösterilmiştir.

Sayfa 63 | 2019; 17 (4); Beşerî Bilimler - İktisadi İdari Bilimler Ortak Sayısı 
Tablo 3. VİF Değerleri

\begin{tabular}{lcc}
\hline Değişken açıllaması & Değişkenler & VíF değeri \\
\hline Hisse başına getiri & $\mathrm{R}$ & 1,05 \\
\hline Denetim komitesi üye sayısı & DKBÜ & 4,63 \\
\hline Denetim komitesi bağımsızlığı & DKBO & 4,88 \\
\hline Denetim komitesi toplantı sayısı & DKTS & 2,85 \\
\hline Denetim komitesi finansal uzmanlığı & DKFU & 1,15 \\
\hline Denetim komitesi üyelerinin ortalama görev süresi & DKGS & 1,35 \\
\hline Yönetim kurulu büyüklüğ̈̈ & YKBÜ & 1,68 \\
\hline Yönetim kurulu bağımsız yönetici oranı & YKBO & 1,96 \\
\hline Yönetim kurulu başkanı ile CEO ayrıysa 1, değilse 0 & YKB-CEO & 1,19 \\
\hline Piyasa Değeri / Defter Değeri & PD/DD & 1,12 \\
\hline Şirket büyüklüğü & ŞBÜ & 1,56 \\
\hline Kaldıraç & KAO & 1,03 \\
\hline
\end{tabular}

\section{Regresyon Sonuçları}

Tablo IV, denetim komitesi özellikleri ile ihtiyatlllık arasındaki ilişkiyi gösteren sabit etkiler regresyon sonuçlarını göstermektedir.

Önceki çalışmalarda (Sultana, 2015; Krishnan ve Visvanathan, 2008) denetim komitesi bağımsızlığının ve finansal uzmanlığının ihtiyatlılık ile istatiksel olarak anlamlı ve pozitif ilişkili olduğu görülmektedir. Ancak analiz sonuçlarına göre denetim komitesi bağımsızlığı ve finansal uzmanlığının ihtiyatlılık ile istatiksel olarak anlamlı bir ilişkisi olmadığı görülmektedir. $\mathrm{Bu}$ durumda $\mathrm{H}_{1}$ ve $\mathrm{H}_{2}$ hipotezleri reddedilmektedir.

Denetim komitesi büyüklüğünün, üyelerinin görev süresinin ve komitenin toplantı sıklığının ihtiyatlılık ile ilişkisi konusunda literatürde karışık sonuçlar mevcuttur. Analiz sonuçlarına göre denetim komitesi büyüklügünü̈n ihtiyatlılık ile istatiksel olarak anlamlı ve pozitif ilişkili olduğu görülmektedir. Elde edilen bu sonuç, Abbott vd. (2004) ve Bedard vd. (2004) ile tutarlılık göstermektedir. Buna göre denetim komitesi üye sayısı arttıkça şirketlerin ihtiyatlılık seviyeleri artmaktadır. Buna gerekçe olarak, üye sayısının artmasının, finansal raporlama süresince ortaya çıkabilecek hataların minimuma indirilmesinde ve yöneticilerin agresif kar yönetimine başvurmalarını engellemesinde etkili olması beklenmektedir. Sonuç olarak, ihtiyatlılık ve denetim komitesi büyüklüğü arasında pozitif ve istatiksel olarak anlamlı bir ilişki olmasından dolayı $\mathrm{H}_{3}$ hipotezi desteklenmiştir.

Analiz sonuçlarına göre, görev süresinin ihtiyatlılık ile istatiksel olarak anlamlı bir ilişki olmadığı görülmektedir. Başka bir ifade ile, denetim komitesi üyelerinin denetim komitesindeki ortalama görev süresi, şirketlerin ihtiyatlılık seviyeleri üzerinde herhangi bir etkisi bulunmamaktadır. Sonuç olarak $\mathrm{H}_{4}$ hipotezi reddedilmektedir.

Analiz sonuçlarına göre, denetim komitesi toplantı sayısının ihtiyatlılık ile istatiksel olarak anlamlı ancak negatifi ilişkili olduğu görülmektedir. Elde edilen bu sonuç, Ghafran ve 
O'Sullivan (2017) ve Appiah ve Amon (2015) ile tutarlık göstermektedir. Buna göre denetim komitesi toplantı sayıları arttıkça şirketlerin ihtiyatlılık seviyeleri azalmaktadır. Buna gerekçe olarak, denetim komitesi toplantılarının artmasının, firmalara ek maliyet yüklemekte ve verimliliği düşürmektedir (toplantı maliyetleri, yöneticilerin zamanlarının büyük bölümü bu toplantılarda geçmesi). Bu durumda da ihtiyatlılık uygulamalarında azalma meydana gelmesi kaçılmaz hale gelmektedir. Sonuç olarak, ihtiyatlılık ve denetim komitesi toplantı sayısı arasında negatif ancak istatiksel olarak anlamlı bir ilişki çıkmasından dolayı $\mathrm{H}_{5}$ hipotezi kabul edilmiştir.

Tablo 4. Panel Veri Regresyon Sonuçları

\begin{tabular}{|c|c|c|c|}
\hline Değişkenler & Beklenen İşaret & Katsay1 & $t$ değeri \\
\hline \multirow[t]{2}{*}{ DKBÜ } & $?$ & $0,003^{* * *}$ & 1,84 \\
\hline & & $(0,001)$ & \\
\hline \multirow[t]{2}{*}{ DKBO } & + & 0,000 & 0,13 \\
\hline & & $(0,001)$ & \\
\hline \multirow[t]{2}{*}{ DKTS } & $?$ & $-0,001^{* * *}$ & $-1,89$ \\
\hline & & $(0.000)$ & \\
\hline \multirow[t]{2}{*}{ DKFU } & + & 0.000 & 0,19 \\
\hline & & $(0.000)$ & \\
\hline \multirow[t]{2}{*}{ DKGS } & $?$ & -0.000 & $-0,41$ \\
\hline & & $(0.000)$ & \\
\hline \multirow[t]{2}{*}{ YKBÜ } & $?$ & $-0.000^{* * *}$ & $-1,68$ \\
\hline & & $(0.000)$ & \\
\hline \multirow[t]{2}{*}{ YKBO } & + & -0.002 & $-0,51$ \\
\hline & & $(0.004)$ & \\
\hline \multirow[t]{2}{*}{ YKB-CEO } & + & -0.000 & $-0,20$ \\
\hline & & $(0.000)$ & \\
\hline \multirow[t]{2}{*}{$\mathrm{PD} / \mathrm{DD}$} & + & $-0,000$ & $-0,02$ \\
\hline & & $(0,000)$ & \\
\hline \multirow[t]{2}{*}{ ŞBÜ } & + & $0,005^{* * *}$ & 1,84 \\
\hline & & $(0,002)$ & \\
\hline \multirow[t]{2}{*}{$\mathrm{KAO}$} & - & $-0,005^{* *}$ & 2,36 \\
\hline & & $(0,002)$ & \\
\hline F-Değeri & 4,83 & & \\
\hline Gözlem Sayısı & 1.180 & & \\
\hline R-Kare Değeri & 0,504 & & \\
\hline
\end{tabular}


Kontrol değişkenlerinin ihtiyatlılık ile ilişkisi incelendiğinde, ihtiyatlılığın, yönetim kurulu büyüklügü ve şirket büyüklüğü ile istatiksel olarak anlamlı ve pozitif ilişki, finansal kaldıraç ile istatiksel olarak anlamlı ve negatif ilişki içinde olduğu görülmektedir. Başka bir ifade ile yönetim kurulundaki yönetici sayısı arttıkça veya şirketin piyasa değerinde bir artış gerçekleştikçe şirketlerin ihtiyatlılık seviyesi artmaktadır. Diğer taraftan, şirketlerin toplam borç / toplam varlık oranı arttıkça şirketlerin ihtiyatlılık seviyesi azalmaktadır. Son olarak, yönetim kurulu bağımsız yönetici oranı, CEO-yönetim kurulu başkanı ayrımı ve piyasa değeri / defter değeri oranlarının ihtiyatlılık ile istatiksel olarak anlamlı bir ilişki içinde olmadığ görülmektedir.

\section{Sonuç}

Yaşanan büyük muhasebe skandalları ve ekonomik krizler, şirketlerin yönetim yapılarında önemli değişikliklere gitmelerine neden olmuştur. Finansal raporların doğru ve güvenilir bilgileri içermesinden ve bu raporların finansal bilgi kullanıcılarına aktarılmasından sorumlu olan yönetim kurulları, bu sorumluluklarını yavaş yavaş denetim komitelerine aktarmaktadır. Denetim komitelerinin de bu sorumlulukları yerine getirebilmesi için belirli özelliklere sahip olması gerekmektedir. Hem literatürde hem de devlet düzenlemelerinde genel kanı, etkin bir denetim komitesinin, bağımsızlık, finansal uzmanlık, boyut, görev süresi, toplantı sıklığı gibi denetim komitesi özelliklerine sahip olması gerektiği yönündedir. Bu özellikler, sermaye piyasasında finansal tablolar aracılığıyla sunulan bilgilerin ve muhasebe uygulamalarının tarafsızlığının ve güvenilirliğinin tesis edilmesine yardımcı olmaktadır.

Denetim komitelerinden beklenen, görevini yerine getirirken kurumsal yönetim uygulamalarında ve şeffaf finansal raporlama sürecinde ihtiyatlı muhasebe politikaları uygulamasıdır. Çünkü, ihtiyatlı muhasebe politikaları, finansal tablolarda sunulan karın kalitesini etkilemekte ve yöneticilerin agresif kar yönetimi uygulamalarını engellemektedir. Bunun sonucunda vekalet maliyeti ve bilgi asimetrisi gibi firma değerini düşürücü problemlerin oluşması önlenmektedir.

Bu kapsamda, çalışmamızın temel amacı, borsada işlem gören finansal olmayan şirketlerin denetim komitesi özellikleri ile ihtiyatlılık seviyeleri arasında ilişki olup olmadığını araştırmaktır. Bulgular, 2012-2016 yılları arasında borsada işlem gören 262 firmadan alınan 1180 gözlem sayısına panel veri analizi uygulanarak elde edilmiştir. Analiz sonuçları, ihtiyatlılığın, denetim komitesi büyüklüğü ile pozitif ilişkili olduğunu, toplantı sıklığı ile negatif ilişkili olduğunu göstermektedir. Başka bir ifade ile denetim komitesi üye sayısı arttıkça ve toplantı sıklığı azaldıkça şirketlerin ihtiyatlılık seviyesi artmaktadır. Bu sonuçlar, literatürdeki çalışmalarla tutarlılık göstermektedir. Ayrıca analiz sonuçları, denetim komitesi üyelerinin bağımsızlığının, finansal uzmanlığının ve görev süresinin ihtiyatlılık ile istatiksel olarak anlamlı bir ilişkisinin olmadığını göstermiştir.

Çalışmamız bazı kısıtlara sahiptir. İlk olarak borsada işlem gören şirketlerin, denetim komitelerini SPK (2011) düzenlemesinden sonra yani 2012 yılı itibariyle oluşturmaları zorunlu hale getirilmiştir. Bu yıldan önce denetim komitesi özelliklerine dair veriler kısıtlıdır. Bu nedenle araştırmamızın kapsamı sadece 2012 ve 2016 yılları arasını kapsamaktadır. İkinci kısıt, şirketlerin ihtiyatlılık seviyelerinin ölçülmesinde literatürde en çok tercih edilen Kar/Hisse Senedi Getirisi modelinin kullanılmasıdır. Ball, Kothari ve Nikolaev, (2013); Dietrich, Muller ve Riedl, (2007); Khan Han ve Watts (2009); Givoly ve Hayn (2000) gibi yazarlar, Kar/Hisse 
Senedi Getirisi modelinin kayda değer yanlılığa (biased) sahip olduğunu ve bundan kaçınılması gerektiğini belirtmiştir. Öte yandan Khan Han ve Watts, (2009); Ball vd., (2013) ise firma büyüklüğü, finansal kaldıraç ve piyasa değeri / defter değeri oranı gibi firma bazlı değişkenlerin göz önünde bulundurulması durumunda Basu modelindeki yanlılığın giderileceğini belirtmiştir. Üçüncü ve son kısıt ise, sadece beş denetim komitesi özelliğinin kullanılmasidır.

Gelecekte yapılacak çalışmalarda, araştırma kapsamı genişletilerek daha fazla gözlem sayısına sahip analizler yapılabilir. Ayrıca Basu modeline ek olarak, literatürde şirketlerin ihtiyatlılık seviyelerini ölçen birçok model kullanılmaktadır. Bu modellerin de tercih edilmesiyle denetim komitesi özellikleri ile ihtiyatlılık arasındaki ilişki test edilebilir. Son olarak denetim komitesi üyelerinin cinsiyeti, başka komitelerde görev alan denetim komitesi üye sayısı, çalışılan bağımsız denetim şirketi gibi değişkenler eklenerek analizin kapsamı genişletilebilir.

\section{Kaynakça}

Abbott, J., L., Parker, S., \& Peters, G. (2004). Audit committee characteristics and restatements, Auditing: A Journal of Practice and Theory, 23(1), 69-87. DOI:10.2308/aud.2004.23.1.69

Acar, D., \& Ahmet, A. (2009). Muhasebede İhtiyatlılık Kavramı ve İMKB Sinai Endeksinde İşlem Gören İşletmelerde İhtiyatlılık Üzerine Bir Araştırma, Afyon Kocatepe Üniversitesi İktisadi ve İdari Bilimler Fakültesi Dergisi, 11 (1), 77-90. Retrieved from https://dergipark.org.tr/tr/pub/akuiibfd/issue/1627/20383

Ağca, A., \& Önder, Ş. (2016). İşletmelerde Kâr Yönetimi ve Kurumsal Yönetim Yapıları Arasındaki İlişki: BIST Üzerine Bir Uygulama, Muhasebe ve Denetime Bakış, (47), 23-42.

Ahmed, A. S., \& Duellman, S. (2007). Accounting Conservatism and Board of Director Characteristics: An Empirical Analysis, Journal of Accounting and Economics, 43 (2-3), 411437. DOI: 10.1016/j.jacceco.2007.01.005

Ahmed, A. S., \& Duellman, S. (2011). Evidence on the Role of Accounting Conservatism in Monitoring Managers' Investment Decisions, Accounting \& Finance, 51 (3), 609- 633. DOI: 10.1111/j.1467-629X.2010.00369.x

Ahmed, K., \& Henry, D. (2012). Accounting conservatism and voluntary corporate governance mechanisms by Australian firms, Accounting \& Finance, 52, 631-662. DOI:10.1111/j.1467629X.2011.00410.x

Agrawal, A., \& Chadha, S. (2005). Corporate governance and accounting scandals, Journal of Law and Economics, 48(2), 371-406. DOI: 10.1086/430808

Aldamen, H., Duncan, K., Kelly, S., Mcnamara, R., \& Nagel, S. (2012). Audit committee characteristics and firm performance during the global financial crisis, Accounting $\mathcal{E}$ Finance, 52, 971-1000. DOI: 10.1111/j.1467-629X.2011.00447.x

Appiah, K. O., \& Amon C. (2015). Board audit committee and corporate insolvency, Journal of Applied Accounting Research, 18(3), 298-316. DOI: 10.1108/JAAR-03-2015-0024

Ball, R., \& Shivakumar, L. (2006). The Role of Accruals in Asymmetrically Timely Gain and Loss Recognition, Journal of Accounting Research 44(2), 207-242. DOI:10.1111/j.1475679X.2006.00198.x 
Ball, R., Kothari, S. P., \& Nikolaev, V. (2013). On Estimating Conditional Conservatism, Accounting Review, 88(3), 755-87. DOI: 10.2308/accr-50371

Basu, S. (1997). The Conservatism Principle and the Asymmetric Timeliness of Earnings, Journal of Accounting and Economics, 24 (1), 3-37. DOI: 10.1016/S0165-4101(97)00014-1

Bebchuk, L. A., Fried, J. M., \& Walker, D. I. (2002). Managerial Power and Rent Extraction in the Design of Executive Compensation, University of Chicago Law Review, 69(3), 751-846. DOI: $10.3386 / \mathrm{w} 9068$

Bedard, J., Chtourou, S. M., \& Courteau, L. (2004). The effect of audit committee expertise, independence, and activity on aggressive earnings management Auditing, Journal of Practice and Theory, 23(2), 13-35. DOI: 10.2308/aud.2004.23.2.13

Beasley, M. S., \& Salterio, S. E. (2001). The relationship between board characteristics and voluntary improvements in audit committee composition and experience, Contemporary Accounting Research 18 (2), 539-570. DOI: 10.1506/RM1J-A0YM-3VMV-TAMV

Beekes, W., Pope, P., \& Young, S. (2004). The link between earnings timeliness, earnings conservatism and board composition: Evidence from the UK, Corporate Governance: An International Review, 12(1), 47-59. DOI: 10.1111/j.1467-8683.2004.00342.x

Bliss, J.H. (1924). Management Through Accounts, The Ronald Press Co. New York.

Bushman, R. M., Piotroski, J. D., \& Smith, A. J. (2004). What Determines Corporate Transparency? Journal of Accounting Research, 42, 207-252. DOI:10.1111/j.1475679X.2004.00136.x

Chancharat, N., Krishnamurti, C., \& Tian, G. (2012). Board structure and survival of new economy IPO firms, Corporate Governance: An International Review, 20(2), 144-163. DOI: 10.1111/j.1467-8683.2011.00906.x

Cadbury Committee (1992). Report of the Committee on Financial Aspects of Corporate Governance. London: HMSO.

Canavan, J., Jones, B., \& Potter, M. J. (2004). Board Tenure: How Long is Too Long? Boards $\mathcal{E}$ Directors, 28(2), 39-42.

Cengiz, S. (2017). Denetim Komitesi Etkinliğinin Denetim Raporlarının Yayınlanma Süresi Üzerindeki Etkisinin İncelenmesi: Borsa İstanbul'da Bir Uygulama. Mali Çözüm Dergisi, 27, (May/Jun 2017), 31-60.

Dhaliwal, D., Naiker, V., \& Navissi, F. (2010). The association between accruals quality and the characteristics of accounting experts and mix of expertise on audit committees, Contemporary Accounting Research, 27(3), 787-827. DOI: 10.1111/j.1911-3846.2010.01027.x

Defond, M. L., \& Francis, J. R. (2005). Audit research after Sarbanes-Oxley, Auditing: A Journal of Practice \& Theory, 24 (S-1), 5-30. DOI: 10.2308/aud.2005.24.s-1.5

Dietrich, D., Muller K., \& Riedl, E. (2007. Asymmetric timeliness tests of accounting conservatism, Review of Accounting Studies, 12 (1). 95- 124. DOI: 10.1007/s11142-006-9023-y

Eken, H., \& Adalı, S. (2008). Piyasa Etkinliği ve İMKB: Zayıf Formda Etkinliğe İlişkin Ekonometrik Bir Analiz, Muhasebe ve Finansman Dergisi, (37), 1-16 
Fakhari, H., \& Pitenoei Y. R. (2017). The Impact of Audit Committee and Its Characteristics on the Firms Information Environment, Iranian Journal of Management Studies (IJMS), 10(3), 577608. DOI: $10.22059 / \mathrm{IJMS} .2017 .231317 .672627$

Fama, E.F. (1970). Efficient capital markets: a review of theory and emprical works. Journal of Finance, 25(2), 383-417.

Financial Accounting Standards Board (FASB), (1975). Accounting for Contingencies, Statement of Financial Accounting Standards No. 5, FASB, Norwalk, CT.

Financial Accounting Standards Board (FASB) (2010), Statement of Financial Accounting Concepts No. 8, Conceptual framework for financial reporting. Norwalk, CT: FASB.

Ghafran, C., \& O'sullivan N. (2017). The impact of audit committee expertise on audit quality: Evidence from UK audit fees, The British Accounting Review, 49(6), 1-16. DOI: 10.1016/j.bar.2017.09.008

Givoly, D. \& Hayn, C. (2000). The Changing Time-Series Properties of Earnings, Cash Flows and Accruals: Has Financial Reporting Become More Conservative? Journal of Accounting and Economics, 29 (3), 287-320. DOI: 10.1016/S0165-4101(00)00024-0

Hellman, N. (2008). Accounting Conservatism under IFRS, Accounting in Europe, 5 (2), 71-100. DOI: $10.1080 / 17449480802510492$

Johnson, J. L., Daily, C. M., \& Ellstrand, A. E. (1996). Boards of directors: A review and research agenda, Journal of Management, 22(3), 409-438. DOI: 10.1016/S0149-2063(96)90031-8

Joseph, V. C., \& Terry L. N. (2003). Audit Committee Independence and Disclosure: choice for financially distressed firms, Corporate Governance: An International Review. 11(4), 289-299. DOI: $10.1111 / 1467-8683.00327$

Joseph, V. C., Carl W., April K., \& Terry L. (2006). Audit Committee Financial Expertise, Competing Corporate Governance Mechanisms, and Earnings Management, SSRN Electronic Journal. DOI: 10.2139/ssrn.887512

Kao, H., \& Chu, T. (2016). Audit committee, supervisor system and accounting conservatism, International Research Journal of Applied Finance, 7(9), 202-219. DOI: 10.0709/article-1

Khan, M., \& Watts, R.L. (2009). Estimation and Empirical Properties of a Firm-year Measure of Accounting Conservatism, Journal of Accounting and Economics, 48 (2-3), 132-150. DOI: 10.1016/j.jacceco.2009.08.002

Klein, A. (2002a). Audit Committee, Board of Director Characteristics, and Earnings Management, Journal of Accounting and Economics. 33(3), 375-400. DOI: 10.1016/S01654101(02)00059-9

Klein, A. (2002b). Economic determinants of audit committee independence, The Accounting Review, 77 (2), 435-452. DOI: 10.2308/accr.2002.77.2.435

Krishnan, J. (2005). Audit committee quality and internal control: An empirical analysis, The Accounting Review, 80(2), 649-675. DOI: 10.2308/accr.2005.80.2.649

Krishnan, G., \& Visvanathan, G. (2008). Does the SOX Definition of an Accounting Expert Matter? the Association between Audit Committee Directors' Accounting Expertise and 
Accounting Conservatism, Contemporary Accounting Research, 25(3), 827-857. DOI:10.2139/ssrn.866884

Krishnan, J., \& Lee J. E. (2009). Audit Committee Financial Expertise, Litigation Risk, and Corporate Governance, Auditing: A Journal of Practice $\mathcal{E}$ Theory. 28(1), 241-261. DOI: 10.2308/aud.2009.28.1.241

Lafond, R., \& Watts, R. (2008). The Information Role of Conservatism, The Accounting Review, 83(2), 447-478. DOI: 10.2308/accr.2008.83.2.447

Lara, J. M., Osma, B., \& Penalva, F. (2009). Accounting Conservatism and Corporate Governance, Review of Accounting Studies, 14(1), 161-201. DOI: 10.1007/s11142-007-9060-1

Lim R. (2011). Are corporate governance attributes associated with accounting conservatism? Accounting \& Finance, 51(4), 1007-1030. DOI: 10.1111/j.1467-629X.2010.00390.x

Lin, F., Wu, C., Fang, T., \& Wun, J. (2014). The relations among accounting conservatism, institutional investors and earnings manipulation, Economic Modelling, 37, 164-174, DOI: 10.1016/j.econmod.2013.10.020.

Liu G. \& Sun J. (2010). Director tenure and independent audit committee effectiveness, International Research Journal of Finance and Economics, 51, 176-189.

Pae, J., Thornton, D. B., \& Welker, M. (2005). The Link between Earnings Conservatism and the Price-to-Book Ratio, Contemporary Accounting Research, 22(3), 693-717. DOI:10.1506/9FDN-N6ED-LJE9-A1HL

Pae, J. (2007). Unexpected Accruals and Conditional Accounting Conservatism, Journal of Business Finance \& Accounting, 34 (5) \& (6), 681-704. DOI:10.1111/j.1468-5957.2007.02018.x

Piot, C. (2004). The existence and independence of audit committees in France, Accounting and Business Research, 34(3), 223-246. DOI: 10.1080/00014788.2004.9729966

Ruch, G. W., \& Taylor, G. (2015). Accounting conservatism: A review of the literature, Journal of Accounting Literature, 34, 17-38. DOI: 10.1016/j.acclit.2015.02.001.

SEC. (2002). Proposed Rule: Disclosure Required by Sections 406 and 407 of the Sarbanes-Oxley Act of 2002. Available at: http://www.sec.gov/ rules /proposed/33-8138.htm.

SEC. (2003). Final Rule: Disclosure Required by Sections 406 and 407 of the Sarbanes-Oxley Act of 2002. Available at: http://www.sec.gov/ rules /final /33-8177.htm.

Sermaye Piyasası Kurulu (SPK). (2011). Kurumsal Yönetim Ilkelerinin Belirlenmesine ve Uygulanmasına İlişkin Tebliğg, http://www.spk.gov.tr/duyurugoster.aspx?aid=20111011 \&subid $=0 \& c t=c$ Erişim Tarihi: 25.11.2015

Sevim, Ş., \& Eliuz, A. (2007). Denetim Komitelerinin İç Denetimin Etkinliği Üzerindeki Rolleri ve İMKB'de Bir Araştırma, Muhasebe ve Finansman Dergisi, 36, 60-70. Retrieved from https://dergipark.org.tr/tr/pub/mufad/issue/35607/395622

Sharma, V. D., Naiker V., \& Lee, B. (2009). Determinants of Audit Committee Meeting Frequency: Evidence from a Voluntary Governance System, Accounting Horizons, 23(2), 245263. DOI: $10.2308 /$ acch.2009.23.3.245 
Sharma, V. D., \& Iselin, E. R. (2012). The association between audit committee multipledirectorships, tenure, and financial misstatements, Auditing: A Journal of Practice $\mathcal{E}$ Theory, 31(3), 149-175. DOI: 10.2308/ajpt-10290

Smith Report. (2003). Audit Committees: Combined Code Guidance. London: Financial Reporting Council.

Sultana, N. (2015). Audit Committee Characteristics and Accounting Conservatism, International Journal of Auditing, 19(2), 88-102. DOI:10.1111/ijau.12034

Temiz, H., Dalkılıç, E., \& Hacıhasanoğlu, T. (2017). Yönetim Kurulu Yapısı ve Kâr Yönetimi Uygulamaları: BİST İmalat Sektörü Örneği, BMIJ, 5(4), 119-136. DOI:10.15295/bmij.v5i4.185

Tuan, K. (2016). Kurumsal Yönetim Endeksinde Yer Alan İşletmelerde Etkin İç Kontrol ve Bağımsız Denetim Göstergeleri, World of Accounting Science, 18(1), 159-183.

Türk Sanayicileri ve İş adamları Derneği (TÜSİAD). (2012). Uygulama Örnekleri ile Birlikte A'dan Z'ye Denetim Komiteleri, Haziran 2012, Yayın No:527. Available at: https:/tusiad.org/tr/yayinlar/raporlar/item/5614-uygulama-ornekleri-ile-birlikte-adanzye-denetim-komiteleri

Vafeas, N. (2003). Length of Board Tenure and Outside Director Independence, Journal of Business Finance \& Accounting, 30 (7-8), 1043-1064. DOI: 10.1111/1468-5957.05525

Yavuzaslan, S., \& Kalmış, H. (2016). İşletmelerde Kurumsal Yönetim Uygulamalarının Kâr Yönetimi Üzerindeki Etkisi ve Borsa İstanbul A.Ş. Şirketleri Üzerinde Bir Uygulama, Yönetim Bilimleri Dergisi, 14(27). 353-384.

Yunos, R. M., Ahmad, S. A., \& Sulaiman, A. (2014). The Influence of Internal Governance Mechanisms on Accounting Conservatism, Procedia - Social and Behavioral Sciences, 164, 501507, DOI:10.1016/j.sbspro.2014.11.138.

Yücel, Ö. (2016). Finansal Piyasa Etkinliği: Borsa İstanbul Üzerine Bir Uygulama, International Review of Economics and Management, 4 (3), 107-123. DOI: 10.18825/irem.16916

Xie, B., Davidson, W. N. \& Dadalt, P. (2003). Earnings management and corporate governance: the role of the board and the audit committee, Journal of Corporate Finance, 9(3), 295-316, DOI: 10.1016/S0929-1199(02)00006-8.

Wang, R., Hogartaigh, C., \& Van, Z. T. (2008). Measures of Accounting Conservatism: A Construct Validity Perspective, Journal of Accounting Literature, 28, 1-60.

Watts, R. L. (2003). Conservatism in Accounting Part I: Explanations and Implications, Accounting Horizons, 17 (3), 207-221. DOI: 10.2139/ssrn.414522

Zalata, A. M., Tauringana, V., \& Tingbani, I. (2018). Audit committee financial expertise, gender, and earnings management: Does gender of the financial expert matter? International Review of Financial Analysis, 55, 170-183, DOI: 10.1016/j.irfa.2017.11.002.

Zeren, F., Kara, H., \& Arı, A. (2013). Piyasa Etkinliği Hipotezi: İMKB İçin Ampirik Bir Analiz, Dumlupınar Üniversitesi Sosyal Bilimler Dergisi, 36, 141-148

Zhong, Y., \& Li, W. (2017). Accounting Conservatism: A Literature Review, Australian Accounting Review, 27, 195-213. DOI:10.1111/auar.12107 